\title{
The Effects of Biological Control using the Composted Liquid Manure on Large Patch in Zoysiagrass (Zoysia japonica)
}

\author{
Ju Hyun Ryu', Gyu Yul Shim², Sang-Kook Lee, and Ki Sun Kim ${ }^{1,4 *}$ \\ ${ }^{1}$ Department of Horticultural Science \& Biotechnology, Seoul National University, Seoul 151-921, Korea \\ ${ }^{2}$ Korea Turfgrass Research Institute, Seongnam 463-840, Korea \\ ${ }^{3}$ Department of Biotechnology, Hoseo University, Asan 336-795, Korea \\ ${ }^{4}$ Research Institute of Agriculture and Life Sciences, Seoul National University, Seoul 151-921, Korea
}

\begin{abstract}
This study was conducted to investigate whether several composted liquid manures (CLMs) are useful for biological control of large patch on zoysiagrass and investigate the chemical and biological factors to suppress large patch in soil treated with CLMs. The CLMs were produced at 4 different facilities for livestock excretion treatments located in Korea. Field experiments were carried out at 5 golf courses located near each facility. CLM and Chemical fertilizer (CF: water soluble fertilizer, 20-20-20) were applied four and three times with $\mathrm{N}$ at $12 \mathrm{~g} \mathrm{~m}^{-2}$ per year, respectively. There was significant increase of concentration of $\mathrm{K}, \mathrm{Na}$, and $\mathrm{Cu}$ of soil treated with CLM compared to CF treatment. Among experimental plots, CN and GG2 plot sites were shown significant higher effect of biological control $80 \%$ and $50 \%$ respectively against large patch disease. The number of bacteria, Actinomycetes, and fungi in soil at these sites significantly increased and fluorescein diacetate hydrolytic activity was enhanced, while the soil was treated with CLM. The results of this study demonstrated that CLM application has effect on soil to suppress large patch and reduce the use of fungicide in environment-friendly turf management.
\end{abstract}

Key words: Compost, Fluorescein diacetate, Suppressive soil, Sustainable management

Received on November 21, 2014; Revised on December 1, 2014; Accepted on December 15, 2014

*Corresponding author: Phone) +82-2-880-4561, Fax) +82-2-873-2056; E-mail) kisun@snu.ac.kr

(C) 2014 The Korean Society of Weed Science and The Turfgrass Society of Korea

This is an Open-Access article distributed under the terms of the Creative Commons Attribution Non-Commercial License \& \#160; (http://creativecommons.org/licenses/by-nc/3.0) which permits unrestricted noncommercial use, distribution, \& \#160; and reproduction in any medium, provided the original work is properly cited.

\section{INTRODUCTION}

Zoysiagrass (Zoysia japonica) is the major warm-season turfgrass for golf course tees, fairways, and sod farms in Korea. Large patch by Rhizoctonia solani AG 2-2 (IV) is one of the most severe diseases in zoysiagrass. Rhizoctonia is difficult to control because of a wide host range, no resistant cultivars, and persistence as mycelium or as sclerotia in the thatch and soil when conditions are not favorable for the growth of turfgrass (Lee et al., 1998). For many years, many golf course superintendents have used chemical fungicides to control soilborne pathogenic diseases (Chang et al., 2007). However, as the interest in the environment increase, there has been a restriction on their uses (Gerhardson, 2002). Accordingly, many researchers have studied to develop new alternatives to chemical fungicides against fungal pathogens, and their concern has focused the antagonistic ability of some microbe
(Welbaum et al., 2004).

Therefore, not only turfgrass managers are looking for suitable substitutes to replace fungicides, but also many researchers are now focusing their studies on non-chemical methods for disease control. Composted materials and substances have long been used by the turfgrass industry as soil conditioners and organic fertilizers (Nelson and Boehm, 2002). Research on biological control of turfgrass diseases has involved the application of organic amendments, usually with a topdressing and a winter cover in the form of composted materials, for the control of several kinds of turfgrass diseases (Noble and Coventry, 2005).

There has been a significant frustration regarding the use of natural organic amendments in turfgrass management due to variable turfgrass responses and unpredictable behavior of these amendments following their application (Ghini et al., 2007). Although a variety of natural organic amendments 
bring about positive growth responses and also reduce the incidence of turfgrass diseases, highly variable and occasionally negative results may be obtained (Garling and Boehm, 2001). Nonetheless, recent experiments have clearly shown the potential for compost amendments to reduce the severity of a wide variety of turfgrass diseases (Noble and Coventry, 2005). There were used many kinds of composts such as bark, brewery and sewage sludge, grass clippings, green waste, and poultry manure for suppressing disease. However, only a few studies on biological control of turfgrass disease with composted liquid manure (CLM) have been found in the literature.

In Korea, the government has promoted a consumption of livestock excretion for various agriculture fields, such as paddy fields, orchards, and greenhouses. All treatment facilities have produced composted liquid manure (CLM) as well as compost. CLM is mostly odorless, homogeneous, pure, humus-like biologically stable organic liquid material with a low nitrate concentration (Ham et al., 2010). It is known to suppress plant diseases with composts through a combination of physiochemical and biological mechanisms. Physiochemical factors such as moisture, nutrient levels, organic matter, and $\mathrm{pH}$ decrease disease occurrence by directly or indirectly affecting the pathogen or host condition (Boulter et al., 2002). Many researchers has carried out studies about biological factors such as microbial populations in compost, microbial competition for nutrients with pathogens (Moody and Gindrat, 1977; Ruppel et al., 1983), antibiotic production (Tu, 1980), parasitism and predation (Liu and Baker, 1980), and induction of host-mediated resistance in plants (Boulter et al., 2002).

Thus, the objectives of this study were to i) investigate whether several CLMs are useful for large patch suppressive on zoysiagrass; ii) determine the chemical and biological factors associated with soil suppressiveness to large patch in soil treated with CLMs
Table 1. Location of experimental sites and composted liquid manure (CLM) production facilities and soil texture of each experimental plots.

\begin{tabular}{lcc}
\hline \hline $\begin{array}{l}\text { Province of } \\
\text { experimental site }\end{array}$ & $\begin{array}{c}\text { City of CLM } \\
\text { facility }\end{array}$ & $\begin{array}{c}\text { Soil texture } \\
\text { (clay + silt, \%) }\end{array}$ \\
\hline Chungbuk (CB) & Cheongwon & Sand (8.8) \\
Chungnam (CN) & Nonsan & Sand (5.1) \\
Gyeongbuk (GB) & Gunwi & Sand (3.0) \\
Gyeonggil (GG1) & Yeoju & Sand (5.3) \\
Gyeonggi2 (GG2) & Yeoju & Loamy sand (12.4) \\
\hline
\end{tabular}

\section{MATERIALS AND METHODS}

\section{CLMs and site description}

The CLMs in this study were produced at 4 different facilities for livestock excretion treatments located in Korea (Table 1). The experiment was conducted at 5 golf courses near each facility for livestock excretion treatment in 2013. Experimental plots were established with medium-leaf ecotype of zoysiagrass (Zoysia japonica). All plots were fertilized three or four times with $3 \mathrm{~g} \mathrm{~N} \mathrm{~m}^{-2}$ at May 1 (GG1 and GG2), Jun. 21, Jul 13, and Sep. 5 in 2013. CLM was applied at $3 \mathrm{~L}$ $\mathrm{m}^{-2}$, since the mean of the total nitrogen concentration of CLMs in 2012 was about $0.98 \mathrm{~g} \mathrm{~L}^{-1}$ and chemical fertilizer (CF) was fertilized at $3 \mathrm{~L} \mathrm{~m}^{-2}$ with Technigro fertilizer (20-20-20, Fisons Horticulture Inc, Warwick, NY, USA). With the exception of fertilization and pesticide applications, experimental plots were managed by management program of each golf courses (CB: fairway; CN, GB, GG1, GG2: rough).

\section{Composted liquid manures}

The chemical and biological properties of CLMs used in 2013 are presented in Table 2. All analyses were performed at the National Instrumentation Center for Environmental Management (Seoul National University, Seoul, Korea). Total

Table 2. The quality of composted liquid manure produced from 4 livestock excretions treatment facilities in 2013.

\begin{tabular}{lcccccccc}
\hline \hline Site & & $\begin{array}{c}\mathrm{pH} \\
(1: 5)\end{array}$ & $\begin{array}{c}\mathrm{EC} \\
(\mathrm{ds} / \mathrm{cm})\end{array}$ & $\begin{array}{c}\mathrm{TDS}^{\mathrm{z}} \\
\left(\mathrm{mg} \mathrm{L}^{-1}\right)\end{array}$ & $\begin{array}{c}\mathrm{T}-\mathrm{N} \\
\left(\mathrm{mg} \mathrm{L}^{-1}\right)\end{array}$ & $\begin{array}{c}\text { Av.P } \\
\left(\mathrm{mg} \mathrm{L}^{-1}\right)\end{array}$ & $\begin{array}{c}\text { Ex.K } \\
\left(\mathrm{mg} \mathrm{L}^{-1}\right)\end{array}$ & $\begin{array}{c}\text { Bacteria } \\
\left(\mathrm{CFU} \mathrm{m} \mathrm{m}^{-1}\right)\end{array}$ \\
\hline $\mathrm{CW}^{y}$ & Range & $7.8-8.0$ & $1.07-1.49$ & $815-875$ & $486-814$ & $163-193$ & $982-2,923$ & $4.03 \times 10^{4}-1.56 \times 10^{6}$ \\
& Avg. & 7.9 & 1.29 & 845 & 647 & 180 & 2,032 & $8.00 \times 10^{5}$ \\
GW & Range & $8.2-8.3$ & $1.62-1.85$ & $545-615$ & $839-2,459$ & $52-227$ & $2,686-2,817$ & $1.45 \times 10^{5}-1.52 \times 10^{6}$ \\
& Avg. & 8.3 & 1.70 & 580 & 1,593 & 128 & 2,752 & $8.33 \times 10^{5}$ \\
NS & Range & $8.4-8.8$ & $0.96-1.12$ & $891-900$ & $642-2,740$ & $114-209$ & $1,479-2,923$ & $1.50 \times 10^{4}-8.87 \times 10^{5}$ \\
& Avg. & 8.6 & 1.02 & 895 & 1,644 & 162 & 2,054 & $4.51 \times 10^{5}$ \\
YJ & Range & $8.4-8.8$ & $0.93-1.12$ & $545-667$ & $555-1,302$ & $19-94$ & $977-1,791$ & $3.44 \times 10^{5}-1.19 \times 10^{6}$ \\
& Avg. & 8.6 & 1.00 & 606 & 851 & 41 & 1,436 & $7.68 \times 10^{5}$ \\
\hline
\end{tabular}

${ }^{2}$ TDS: total dissolved solid; T-N: total nitrogen; Av.P: available $\mathrm{P}_{2} \mathrm{O}_{5}$; Ex.K: exchangeable potassium; CFU: colony forming unit.

${ }^{y}$ CW: Cheongwon; GW: Gunwi; NS: Nonsan; YJ: Yeoju. 
$\mathrm{N}$ was measured using the Kjeldahl method (Bremner, 1996). Other nutrients were quantified using inductively coupled plasma spectrophotometry (ICP; 730-ES, Varian, USA) after acid digestion (NIAST, 2000). Total dissolved solids (TDS), $\mathrm{pH}$, and EC were measured using a portable $\mathrm{pH} / \mathrm{EC} / \mathrm{TDS}$ / Temperature Meter (HI9811-5, Hanna instruments Inc, Woonsocket, RI, USA) before CLM application. The number of bacteria were counted as colonies forming units (CFUs) on nutrient agar. For each CLM sample, aliquots of $100 \mu \mathrm{L}$ from dilutions were applied to Petri dishes containing the cultural medium, and incubated upside down at $25^{\circ} \mathrm{C}$ until colonies were visible after $24 \mathrm{~h}$ for bacteria.

\section{Disease assessment}

Disease severity was estimated in October, 2013 using the digital image analysis method to quantify the percentage of the large patch lesion present in a subsection of each plot. Experimental plots were photographed biweekly using the automatic settings of a digital camera (Nikon D80, Nikon Inc., Tokyo, Japan) placed $1.5 \mathrm{~m}$ above the turf canopy. Plots were manually brushed to remove dead grass clippings and fallen leaves prior to being photographed.

Batch analysis of digital images was performed with SigmaScan Pro software (version 5.0, Jandel Scientific, Chicago, IL, USA) using a SigmaScan Pro macro named 'Turf Analysis' (Karcher and Richardson, 2005). The threshold settings were adjusted to hue $=15-42$ and saturation $=10-60$ (Obasa et al., 2013). These threshold settings allowed the estimation of pixels (expressed as percentages) that represented non-green turf relative to green turf.

\section{Abiotic soil characteristics}

For the determination of soil chemical properties, we took soil samples using a hole cutter and prepared the soil at $3 \mathrm{~cm}$ below thatch layer of samples by using the knife. And clay contents of soil samples were evaluated by micropipette method (Miller and Miller, 1987). The following chemical properties were estimated, for each soil sample: $\mathrm{NO}_{3}-\mathrm{N}, \mathrm{NH}_{4}{ }^{-}$ $\mathrm{N}$, exchangeable cations $(\mathrm{K}, \mathrm{Ca}, \mathrm{Mg}$, and $\mathrm{Na}) . \mathrm{NO}_{3}-\mathrm{N}$ and $\mathrm{NH}_{4}-\mathrm{N}$ were measured using the Kjeldahl method (Bremner, 1996). Exchangeable cations were extracted with $1 \mathrm{~N}$ ammonium acetate. The extracted solutions were analyzed with inductively coupled plasma spectrophotometry (ICP; 730-ES, Varian, USA) after dilution (NIAST, 2000).

\section{Biotic soil characteristics}

Soil samples of $3 \mathrm{~cm}$ deep taken out from soil surface were used for the determination of soil biological properties in October, 2013. The following biotic variables were evaluated for each soil sample: total microbial activity, culturable bacterial, fungal, and actinomycetes communities. The total microbial activity of the soil was evaluated by overall enzymatic activity (hydrolysis of fluorescein diacetate, FDA).

For FDA hydrolysis, the method of Chen et al. (1988) was used. Soil samples $(2 \mathrm{~g})$ were placed in $100 \mathrm{~mL}$ Erlenmeyer flasks and mixed with $20 \mathrm{~mL}$ of potassium phosphate buffer $(60 \mathrm{mM} ; \mathrm{pH} 7.6)$. The hydrolysis reaction was triggered by the addition of $0.2 \mathrm{~mL}$ of FDA stock solution $\left(2 \mathrm{mg} \mathrm{FDA} \mathrm{mL}^{-1}\right.$ acetone) and the flasks were incubated on a rotary shaker (200 $\mathrm{rpm})$ at $25^{\circ} \mathrm{C}$ for $20 \mathrm{~min}$. The reaction was halted by the addition of $20 \mathrm{~mL}$ of acetone per flask, and the content of each flask was filtered on Whatman No.1. filter paper. The absorbance $(490 \mathrm{~nm})$ of the filtrate was determined spectrophotometrically. To determine the concentration of the hydrolyzed fluorescein ( $\mu$ g fluorescein $\mathrm{g}^{-1}$ of dry soil), the absorbance of the samples were compared against a standard curve, obtained by following the same methodology, except that a known concentration of FDA was added to the potassium phosphate buffer and the flasks were kept at $100^{\circ} \mathrm{C}$ for $60 \mathrm{~min}$ to hydrolyze the FDA before it was mixed with the soil samples.

All other variables were assessed by counting colonies forming units (CFUs) on potato dextrose agar for fungi, plate counting agar for bacteria, and alkalinized water-agar medium (pH 10.5) for actinomycetes. For each soil sample, aliquots of $100 \mu \mathrm{L}$ from dilutions were applied to Petri dishes containing the cultural medium, and incubated upside down at $25^{\circ} \mathrm{C}$ until colonies were visible (after one day for bacteria, two days for general fungi, and five days for actinomycetes).

\section{Statistical analysis}

At each site, treatment plots were arranged in a split-plot design with fertilization (versus non-fertilization) as the parameter for the sub-plot $(1.0$ by $2.0 \mathrm{~m})$. There were three blocks leading to three replicate plots per treatment. All statistical analyses were conducted by SAS version 9.3 (SAS Institute Inc., Cary, NC, USA). Means of soil chemical properties were calculated by a one way ANOVA. Only differences between the chemical fertilizer and CLM treatment on abiotic and biotic factors were compared by $\mathrm{t}$-tests.

\section{Results and Discussion}

\section{Large patch severity}

The influence of CLM on large patch severity at experimental plots in zoysiagrass is shown in Fig. 1. Because there was no large patch disease incidence in site GG1, data for the site GG1 are not shown. Large patch severity varied among experimental sites. Although there was no significant difference, smaller patch incidence was observed in CLM-treated plot of site CN (treated with CLM produced at Nonsan facility) and site GG2 (Yeoju facility) as compared with untreated plots by $80 \%$ and $50 \%$, respectively. Ushiwata et al. (2009) reported that R. solani AG-4 (isolate SN-1) growth was inhibited by using the liquid residue derived from stream-treated grass clippings. With 


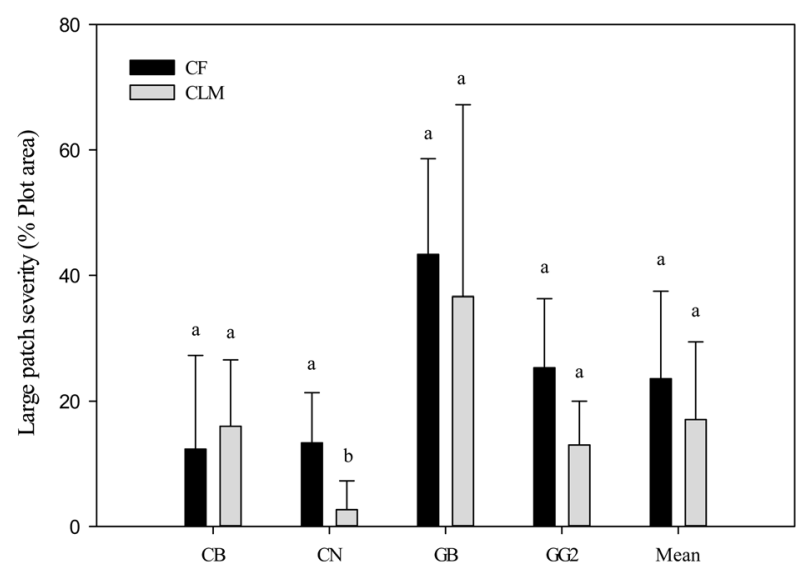

Fig. 1. Influence of composted liquid manure on large patch severity in zoysiagrass as measured by digital image analysis at 4 experimental sites in October, 2013. CF: chemical fertilizer; CLM: composted liquid manure; CB: Chungbuk; CN: Chungnam; GB: Gyeongbuk; GG2: Gyeonggi2. Vertical bars indicate the standard errors and means followed by the same letter on bars are notsignificantly different tested by Student's t-test $(P=0.05)$. compost such as sludge, animal manure, horticultural waste, and natural organic fertilizer, the suppression of turfgrass disease observed is caused not only by increased water holding capacity and improved nitrogen nutrition (Nelson and Boehm, 2002). Conversely, in site CB, the turf treated with CLM showed a tendency to slightly increase large patch incidence than turf treated with CF. Hoitinka and Grebusa (1994) demonstrated that immature composts supply food for pathogens and increase disease despite the presence of biocontrol agents. On the contrary, excessively stabilized organic matter does not provide for the activity of biocontrol agents. Ghini et al. (2007) also showed that when they applied sewage sludge to vegetable crops such as bean, tomato, and cucumber, the soil-borne plant pathogens such as Sclerotium rolfsii, Sclerotinia sclerotiorum, $R$. solani, and Ralstonia solanacearum decreased. Further, they reported that the effects of sewage sludge varied depending on the specific pathogen and methodology applied, as well as the time interval between the sewage sludge incorporation and soil sampling. We assumed that a variance of biological activity of

Table 3. Chemical properties of the experimental plot after the fertilization in 2013.

\begin{tabular}{|c|c|c|c|c|c|c|c|c|c|c|c|c|c|c|c|}
\hline \multirow[b]{2}{*}{ Site } & \multirow[b]{2}{*}{ Month } & \multicolumn{2}{|c|}{$\begin{array}{l}\mathrm{NO}_{3}-\mathrm{N} \\
\left(\mathrm{mg} \mathrm{kg}^{-1}\right)\end{array}$} & \multicolumn{2}{|c|}{$\begin{array}{l}\mathrm{NH}_{4}-\mathrm{N} \\
\left(\mathrm{mg} \mathrm{kg}^{-1}\right)\end{array}$} & \multicolumn{2}{|c|}{$\begin{array}{c}\mathrm{K} \\
\left(\mathrm{cmol}_{\mathrm{c}} \mathrm{kg}^{-1}\right)\end{array}$} & \multicolumn{2}{|c|}{$\begin{array}{c}\mathrm{Ca} \\
\left(\mathrm{cmol}_{\mathrm{c}} \mathrm{kg}^{-1}\right)\end{array}$} & \multicolumn{2}{|c|}{$\begin{array}{c}\mathrm{Mg} \\
\left(\mathrm{cmol}_{\mathrm{c}} \mathrm{kg}^{-1}\right)\end{array}$} & \multicolumn{2}{|c|}{$\begin{array}{c}\mathrm{Na} \\
\left(\mathrm{cmol}_{\mathrm{c}} \mathrm{kg}^{-1}\right)\end{array}$} & \multicolumn{2}{|c|}{$\begin{array}{c}\mathrm{Cu} \\
\left(\mathrm{cmol}_{\mathrm{c}} \mathrm{kg}^{-1}\right)\end{array}$} \\
\hline & & $\mathrm{CF}^{\mathrm{z}}$ & CLM & $\mathrm{CF}$ & CLM & $\mathrm{CF}$ & CLM & $\mathrm{CF}$ & CLM & $\mathrm{CF}$ & CLM & $\mathrm{CF}$ & CLM & $\mathrm{CF}$ & CLM \\
\hline \multirow[t]{2}{*}{$\mathrm{CB}^{\mathrm{x}}$} & Aug. & 82.6 & 77.5 & 11.6 & 10.5 & 0.6 & 1.7 & 7.4 & 13.3 & 2.2 & 1.0 & 2.7 & 0.6 & 0.25 & 0.16 \\
\hline & Oct. & 40.7 & 41.7 & 10.8 & 13.2 & 1.4 & 1.4 & 4.8 & 4.2 & 4.8 & 2.5 & 3.0 & 3.3 & 0.17 & 0.50 \\
\hline \multirow[t]{2}{*}{$\mathrm{CN}$} & Aug. & 82.9 & 29.5 & 6.6 & 11.1 & 1.6 & 2.0 & 3.1 & 5.7 & 7.9 & 6.3 & 0.9 & 4.5 & 0.25 & 0.32 \\
\hline & Oct. & 41.5 & 18.4 & 1.2 & 5.3 & 2.1 & 1.2 & 7.3 & 6.4 & 7.1 & 10.2 & 1.0 & 2.3 & 0.24 & 0.55 \\
\hline \multirow[t]{2}{*}{ GB } & Aug. & 91.9 & 35.1 & 10.0 & 14.1 & 1.5 & 2.2 & 4.3 & 12.4 & 5.8 & 4.0 & 3.1 & 2.1 & 0.25 & 0.02 \\
\hline & Oct. & 82.3 & 69.8 & 3.5 & 1.0 & 0.9 & 1.8 & 5.0 & 5.6 & 3.8 & 3.0 & 4.6 & 4.4 & 0.38 & 0.19 \\
\hline \multirow[t]{2}{*}{ GG } & Aug. & 32.0 & 37.1 & 7.8 & 5.8 & 0.8 & 2.1 & 12.2 & 3.5 & 6.6 & 2.7 & 2.8 & 4.3 & 0.08 & 0.07 \\
\hline & Oct. & 48.9 & 37.9 & 11.1 & 8.7 & 0.9 & 1.5 & 13.6 & 12.9 & 9.9 & 5.5 & 1.4 & 0.7 & 0.52 & 0.46 \\
\hline \multirow[t]{2}{*}{ GG2 } & Aug. & 26.0 & 45.2 & 7.8 & 5.8 & 0.8 & 2.1 & 12.2 & 3.5 & 6.6 & 2.7 & 2.8 & 4.3 & 0.08 & 0.07 \\
\hline & Oct. & 56.2 & 40.3 & 11.1 & 8.7 & 0.9 & 1.5 & 13.6 & 12.9 & 9.9 & 5.5 & 1.4 & 0.7 & 0.52 & 0.46 \\
\hline \multirow[t]{2}{*}{ Mean } & Aug. & 63.1 & 44.9 & 7.4 & 8.6 & 1.1 & 2.0 & 7.1 & 8.9 & 6.4 & 3.2 & 3.2 & 2.5 & 0.23 & 0.17 \\
\hline & Oct. & 53.9 & 41.6 & 6.5 & 6.8 & 1.2 & 1.5 & 8.6 & 6.8 & 6.6 & 5.5 & 5.5 & 2.5 & 0.35 & 0.46 \\
\hline \multicolumn{16}{|l|}{ t-test } \\
\hline \multicolumn{2}{|c|}{ Fertilizer (F) } & \multicolumn{2}{|c|}{ * } & \multicolumn{2}{|c|}{ NS } & \multicolumn{2}{|c|}{ ** } & \multicolumn{2}{|c|}{ NS } & \multicolumn{2}{|c|}{ NS } & \multicolumn{2}{|c|}{ * } & \multicolumn{2}{|c|}{ * } \\
\hline \multicolumn{2}{|c|}{ Time $(\mathrm{T})$} & \multicolumn{2}{|c|}{ NS } & \multicolumn{2}{|c|}{ NS } & \multicolumn{2}{|c|}{ NS } & \multicolumn{2}{|c|}{ NS } & \multicolumn{2}{|c|}{ NS } & & JS & & ** \\
\hline ANOV & & & & & & & & & & & & & & & \\
\hline Site $(S)$ & & & ** & & IS & & JS & & JS & & JS & & JS & & JS \\
\hline $\mathrm{F}^{*} \mathrm{~S}$ & & & JS & & IS & & JS & & JS & & JS & & JS & & JS \\
\hline $\mathrm{T}^{\star} \mathrm{S}$ & & & JS & & IS & & IS & & JS & & JS & & JS & & * \\
\hline $\mathrm{F}^{\star} \mathrm{T}^{\star}$ & & & JS & & IS & & JS & & JS & & JS & & JS & & JS \\
\hline
\end{tabular}

${ }^{\mathrm{z}}$ Fertilizer treated on May, July, August, and September in 2013.

${ }^{y} \mathrm{CF}$ : chemical fertilizer; CLM: composted liquid manure.

${ }^{x} \mathrm{CB}$ : Chungbuk; CN: Chungnam; GB: Gyeongbuk; GG1: Gyeonggil; GG2: Gyeonggi2.

NS, ${ }^{*},{ }^{* *},{ }^{* *}$ Nonsignificant or significant at $P=0.05,0.01$, and 0.001 level, respectively. 


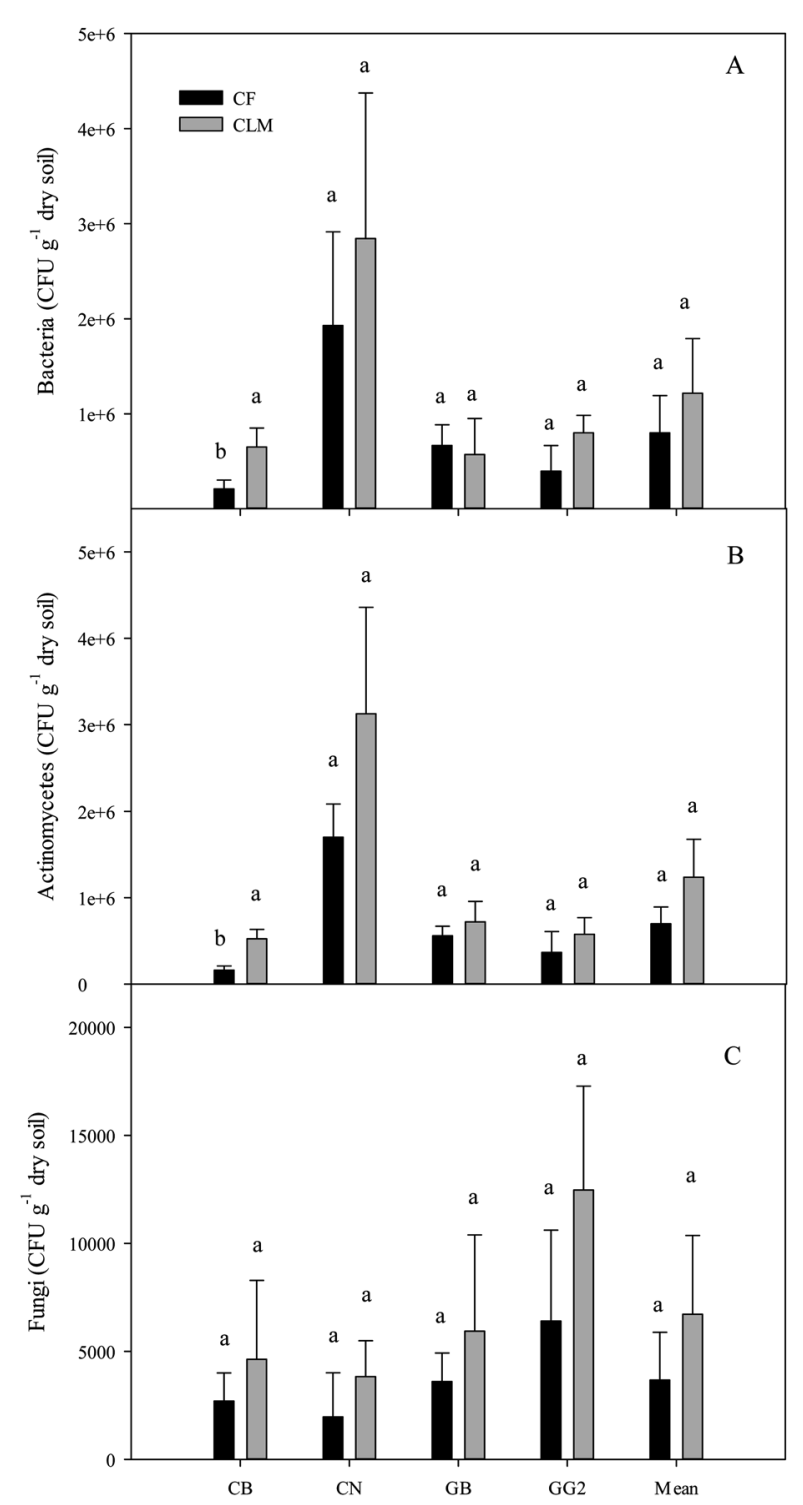

Fig. 2. Changes of population of bacteria (A), Actinomycetes (B), and fungi $(\mathrm{C})$ in soil receiving composted liquid manure at 4 experimental sites in October, 2013. CF: chemical fertilizer; CLM: composted liquid manure; CB: Chungbuk; CN: Chungnam; GB: Gyeongbuk; GG2: Gyeonggi2. Vertical bars indicate the standard errors and means followed by the same letter on bars are notsignificantly different tested by Student's t-test $(P=0.05)$.

CLM came from other edaphic variables such as soil and biological properties.

\section{Abiotic soil characteristics}

According to the particle size distribution of the soil sample, their soil texture was evaluated as sand except site GG2, which is loamy sand (Table 1). Site GG2 showed the most clay contents than any other sites. Duffy et al. (1997) found that the biocontrol of take-all of wheat by Trichoderma koningii was positively correlated with percent clay.
There was significant difference in $\mathrm{NO}_{3}-\mathrm{N}$ content depending on fertilizer treatments and among experimental sites (Table 3). Turf treated with CF showed 65\% higher NO3$\mathrm{N}$ content in the soil compared to CLM treatment. It was 82.9 $\mathrm{mg} \mathrm{kg}^{-1}$ and $41.5 \mathrm{mg} \mathrm{kg}^{-1}$ when the soil was treated with CF, whereas the average $\mathrm{NO}_{3}-\mathrm{N}$ in the CLM treated soil of site $\mathrm{CN}$ was $29.5 \mathrm{mg} \mathrm{kg}^{-1}$ of soil in August and $18.4 \mathrm{mg} \mathrm{kg}^{-1}$ of soil in October, respectively. The site GB's plot showed the highest $\mathrm{NO}_{3}-\mathrm{N}$ contents than other plots. Soil K content showed a statistically significant difference between fertilizer treatments. CLM treatments increased by $46 \% \mathrm{~K}$ content of soil compared with CF treatment. Increase of soil $\mathrm{K}$ content of plots treated with CLM might be attributed to higher concentration of $\mathrm{K}$ within CLM.

Sodium showed a significant difference between fertilizer treatments, even though there was no significant difference in $\mathrm{NH}_{4}-\mathrm{N}, \mathrm{Ca}$, and $\mathrm{Mg}$ contents among any factors. CLM treated plot showed 33\% higher Na content than CF treated plot. In the case of $\mathrm{Cu}$, significant difference in fertilizer treatments and times was also shown. Significant time $\times$ site interactions were observed in $\mathrm{Cu}$ content. Soil chemical properties such as boron, copper, iron, soluble magnesium, and $\mathrm{NO}_{3}-\mathrm{N}$ were associated with enhanced biocontrol of take-all by Trichoderma koningii (Duffy et al., 1997). In our study, it also demonstrated the difference of large patch severity between fertilizer treatments of experimental site was associated with $\mathrm{NO}_{3}-\mathrm{N}$, potassium, sodium, and copper, although there was no statistically significant difference. Chang et al. (2007) suggested that contents of $\mathrm{NO}_{3}-\mathrm{N}$ and $\mathrm{NH}_{4}-\mathrm{N}$ in the root zone soil might affect directly or indirectly as a factor to occurrence of large patch. Also, abiotic variables $(\mathrm{P}, \mathrm{K}, \mathrm{Ca}, \mathrm{Mg}, \mathrm{Na}, \mathrm{Cu}$,

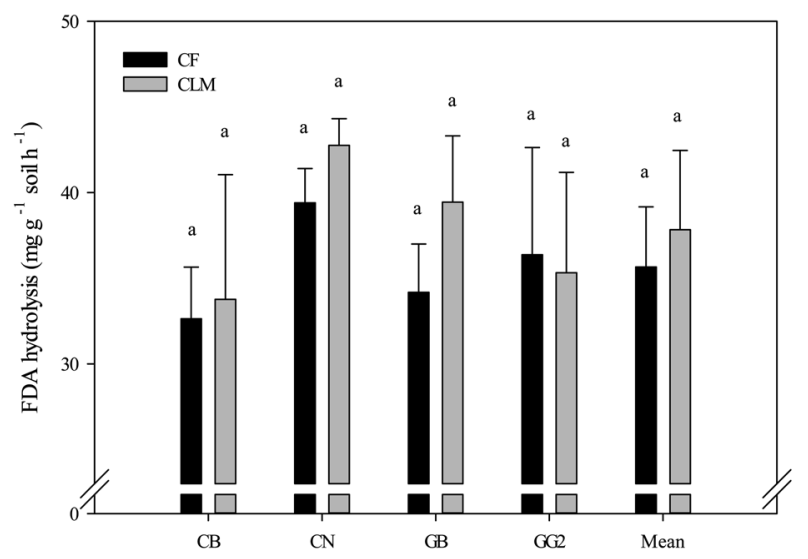

Fig. 3. Changes of fluorescein diacetate hydrolysis in soil receiving composted liquid manure at 4 experimental sites in October, 2013. CF: chemical fertilizer; CLM: composted liquid manure; CB: Chungbuk; CN: Chungnam; GB: Gyeongbuk; GG2: Gyeonggi2. Vertical bars indicate the standard errors and means followed by the same letter on bars are not-significantly different tested by Student's t-test $(P=0.05)$. 


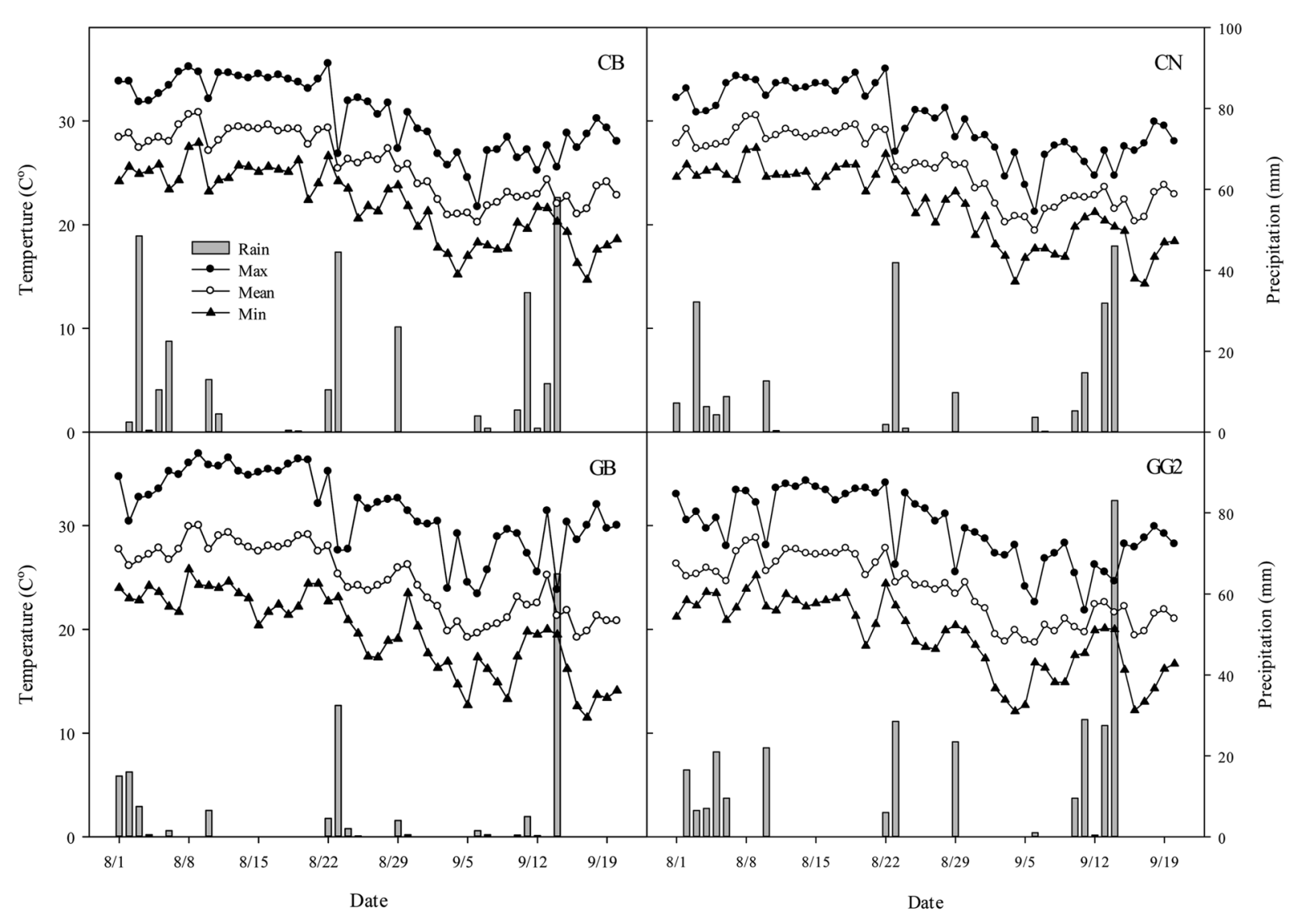

Fig. 4. Daily air temperature of maximum, mean, and minimum and precipitation recorded in each experimental sites from August to September, 2013. CB: Chungbuk; CN: Chungnam; GB: Gyeongbuk; GG2: Gyeonggi2.

and CEC) were correlated with $R$. solani growth suppression (Ghini and Morandi, 2006). In case of $\mathrm{N}$ and $\mathrm{K}$, high $\mathrm{N}$ or low $\mathrm{K}$ favored disease development, whereas low $\mathrm{N}$ or high $\mathrm{K}$ retarded it (Walker and Foster, 1946). In the previous experiments, it was found that the amount of $\mathrm{N}$ and $\mathrm{K}$ within CLMs averaged $0.1 \%$ and $2 \%$, respectively. Therefore, use of CLM on zoysiagrass maintenance could contribute to the biological control on large patch.

\section{Biotic soil characteristics}

There was no significant difference in total number of bacteria, Actinomycetes, and fungi between fertilizer treatments (Fig. 2). However, overall value of CLM treated plots tended to have more population compared to $\mathrm{CF}$ treated plots. Population of bacteria tended to increase more than two times at site $\mathrm{CB}$ with CLM treatment, respectively. Although the number of bacteria in Nonsan CLM was the fewest, that in the soil of CN site plot was the largest among other sites. Actinomycetes which has been known to have antibiotic activity tended to increase at site CB like bacteria, when the soil was treated with CLM. Fungi at site GG2 showed more increase than other site. Disease rate in the field was negatively correlated with the mean of total number of bacteria $(\mathrm{r}=-0.49)$ and Actinomycetes $(\mathrm{r}=$ 0.43 ). The suppression of turfgrass disease observed is caused by elevated soil populations of bacteria and fungi when several types of compost applied (Nelson and Boehm, 2002). Microbial populations in compost tea are considered the most significant factor contributing to foliar disease suppression (Scheuerell and Mahaffee, 2002). Sewage sludge can contribute to the control of plant disease, particularly in view of its capacity to stimulate the soil microbiota, because of its rich organic matter content (Santos and Bettiol, 2003). To the contrary, Ghini and Morandi (2006) said that colony counts of bacterial, fungal and actinomycetes communities on the selective media were not correlated with soil suppressiveness to R. solani. However, Chang et al. (2007) found that population of Bacillus spp., Actinomyces spp., and Pseudomonas spp. were higher in the soil of healthy plant than that of large patch and supported that might be the relationship between population of microbes in soil and occurrence of large patch.

Despite no significant difference between fertilizer treatments, FDA hydrolytic activity tended to increase by CLM treatment compared with $\mathrm{CF}$ treatment. In the case of site $\mathrm{CN}$ and GB, the FDA hydrolytic activity of CLM treated plots was higher 
than that of CF treated with plot. At the highly suppressive areas, FDA hydrolysis was correlated with growth suppression of R. solani (Ghini and Morandi, 2006). The total microbial activity, inferred by the amount of hydrolyzed FDA, was positively and highly correlated with the pathogen suppression at the pasture and fallow ground and forested areas (Ghini and Morandi, 2006).

As the interest in sustainable turf management increases, there is a growing need to use CLM on turfgrass. In summary, CLM treatment could not only change the abiotic soil characteristics such as soil chemical properties $\left(\mathrm{NO}_{3}-\mathrm{N}, \mathrm{K}, \mathrm{Na}\right.$, and $\mathrm{Cu}$ ), but also the biotic soil characteristics such as the number of bacteria, Actinomycetes, and fungi in soil and microbial community function (FDA). Although there was no significant difference, the suppressiveness of large patch growth was shown at the several CLM treated plots. There were a similar air temperature patterns of each sites (Fig. 4). In the case of GB site, it rained less than other site at August, 2013, however, it showed more severity of large patch. These effects of the biological control to large patch could, therefore, be derived from the change of abiotic and biotic soil properties with CLM. As a results, we recommend frequent application of CLM as the low rate fertilizer, because natural suppressiveness is frequently associated with the physical properties of soils and is relatively independent of turf management (Chandrashekara et al., 2012). However, the effects of CLMs varied depending on different chemical constituents and composting degree with production length and treatment facilities. Thus, the long-term effects of CLM on soil biological and chemical characteristics in zoysiagrass maintenance should be investigated, especially about bacteria such as Bacillus spp. and Actinomycetes spp. In addition, a further in-depth study is needed to characterize the mechanism of biological control of large patch in zoysiagrass by CLM.

\section{Acknowledgement}

This study was financially supported by an AGENDA (No: PJ008456032014) grant of Rural Development Administration, Republic of Korea.

\section{REFERENCES}

Boulter, J.I., Boland, G.J. and Trevors, J.T. 2002. Evaluation of composts for suppression of dollar spot (Sclerotinia homoeocarpa) of turfgrass. Plant Dis. 86:405-410.

Bremner, J.M. 1996. Nitrogen-total, pp. 1085-1121. In: J.M. Bartels and D.L. Sparks (eds.). Methods of soil analysis. Part 3-Chemical methods. Soil Sci. Soc. Am., Madison, WI.

Chandrashekara, C., Kumar, R., Bhatt, J.C. and Chandrashekara, K.N. 2012. Eco-friendly Innovative Approaches in Plant Disease Management. Ch. 14. pp. 241-256. Oscar Publications,
DEL, India.

Chang, T.H., Ru, Y.J. and Lee, Y.S. 2007. Soil mineral nutrients and microbes are responsible for large patch disease caused by Rhizoctonia solani AG2-2 in zoysiagrass turf. Kor. Turfgrass Sci. 21:113-126

Chen, W., Hoitink, A.J., Schmittenner, A.F. and Tuovinen, O.H. 1988. The role of microbial activity in suppression of dampingoff caused by Pythium ultimum. Phytopathol. 78:314-322.

Duffy, B.K., Ownley, B.H. and Weller, D.M. 1997. Soil chemical and physical properties associated with suppression of take-all of wheat by Trichoderma koningii. Phytopathol. 87:1118-1124.

Garling, D.C. and Boehm, M.J. 2001. Temporal effects of compost and fertilizer applications on nitrogen fertility of golf course turfgrass. Agron. J. 93:548-555.

Gerhardson, B. 2002. Biological substitutes for pesticides. Trends Biotechnol. 20:338-343.

Ghini, R. and Morandi, M.B. 2006. Biotic and abiotic factors associated with soil suppressiveness to Rhizoctonia solani. Sci. Agric. 63:153-160.

Ghini, R., Patrýcio, F.R.A., Bettiol, W., Almeida, I.M.G. and Maia, A.H.N. 2007. Effect of sewage sludge on suppressiveness to soilborne plant pathogens. Soil Biol. Biochem. 39:2797-2805.

Ham, S.K., Kim, Y.S. and Park, C.H. 2010. The growth effects of creeping bentgrass by SCB (slurry composting and biofilteration) liquid fertilizer application. Kor. Turfgrass Sci. 24:56-61. (In Korean)

Hoitinka, H.A.J. and Grebusa, M.E. 1994. Status of biological control of plant diseases with composts. Compost Sci. Utilization 2:6-12.

Karcher, D.E. and Richardson, M.D. 2005. Batch analysis of digital images to evaluate turfgrass characteristics. Crop Sci. 45:15361539.

Lee, S.J., Shim, K.K., Kim, Y.K. and Hue, K.Y. 1998. Suppression of Rhizoctonia spp. by antagonistic microorganisms and their compatibility with fungicides. Kor. Turfgrass Sci. 12:23-30. (In Korean)

Liu, S. and Baker, R. 1980. Mechanism of biological control in soils suppressive to Rhizoctonia solani. Phytopathol. 70:404-412.

Miller, W.P. and Miller, D.M. 1987. A micropipette method for soil mechanical analysis. Commun. Soil Sci. Plant Anal. 18:1-15.

Moody, A.R. and Gindrat, D. 1977. Biological control of cucumber black root rot by Gliocladium roseum. Phytopathol. 67:11591162.

Naidu, Y., Meon, S. and Siddiqui, Y. 2012. In vitro and in vivo evaluation of microbial-enriched compost tea on the development of powdery mildew on melon. BioControl 57:827-836.

Nelson, E.B. and Boehm, M.J. 2002. Compost-induced suppression of turf grass diseases. BioCycle 43:51-51.

NIAST (National Institute of Agricultural Science and Technology). 2000. Methods of soil and plant analysis. National Institute of Agricultural Science and Technology, RDA, Suwon, Korea.

Noble, R. and Coventry, E. 2005. Suppression of soil-borne plant 
diseases using composts: a review. Biocontrol Sci. Technol. 15:3-20

Obasa, K., Fry, J., St. John, R. and Kennelly, M. 2013. Effect of cultivation and timing of nitrogen fertilization on large patch disease of zoysiagrass. Plant Dis. 97:1075.

Ruppel, E.G., Baker, R., Harman, G.E., Hubbard, J.P., Hecker, R.J., et al. 1983. Field tests of Trichoderma harzianum Rifai aggr. as a biocontrol agent of seedling disease in several crops and Rhizoctonia root rot of sugar beet. Crop Prot. 2:399-408.

Santos, I. and Bettiol, W. 2003. Effect of sewage sludge on the rot and seedling damping-off of bean plants caused by Sclerotium rolfsii. Crop Prot. 22:1093-1097.

Scheuerell, S.J. and Mahaffee, W.F. 2002. Compost tea: principles and prospects for plant disease control. Compost Sci. Utiliza- tion 10:313-338.

Tu, C.M. 1980. Influence of five pyrethroid insecticides on microbial populations and activities in soil. Microb. Ecol. 5:321-327.

Ushiwata, S.Y., Amemiya, Y. and Inubushi, K. 2009. Inhibition of in vitro growth of Rhizoctonia solani by liquid residue derived from steam-treated grass clippings. J. General Plant Pathol. 75:312-315.

Walker, J.C. and Foster, R.E. 1946. Plant nutrition in relation to disease development. III. Fusarium wilt of tomato. Am. J. Bot. 33:259-264.

Welbaum, G.E., Sturz, A.V. Dong, Z. and Nowak, J. 2004. Managing soil microorganisms to improve productivity of agro-ecosystems. Crit. Rev. Plant Sci. 23:175-193. 